\title{
The Effects of Sodium Chloride versus Sodium Bicarbonate at the Same Dietary Sodium Concentration on Efficacy of Dietary Phytase and a Carbohydrase-Protease Cocktail in Broilers
}

http://dx.doi.org/10.1590/1806-9061-2019-1192

\section{author(s)}

Argüelles-Ramos M' (iD https://orcid.org/0000-0003-2168-722X Brake J"

Department of Animal and Veterinary Sciences, Clemson University, Clemson, SC 29634-0303 USA.

" Prestage Department of Poultry Science, North Carolina State University, Raleigh, NC 276957608 USA.

The use of trade names in this publication does not imply endorsement of the products mentioned nor criticism of similar products not mentioned.

\section{-Mail Address}

Corresponding author e-mail address Mireille Argüelles-Ramos

Clemson University,

Department of Animal and Veterinary

Sciences, Clemson, SC 29634, USA.

Phone: +1 (864) 656-6969

Email: marguel@clemson.edu

\section{- Keywords}

Broilers, carbohydrase-protease cocktails, chloride, phytase, sodium bicarbonate.

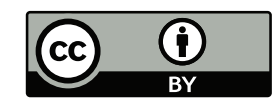

Submitted: 28/November/2019 Approved: 07/April/2020

\section{ABSTRACT}

A trial was conducted to determine the effect of phytase (PHY) or a carbohydrase/protease cocktail (CPX) on broilers fed diets with two different levels of chloride $(0.28 \%$ or $0.43 \%)$ created by altering dietary salt $(\mathrm{NaCl})$ and sodium bicarbonate $\left(\mathrm{NaHCO}_{3}\right)$. There were 6 combination dietary treatments (3 enzyme $\times 2 \mathrm{NaCl}$ treatments) applied to 4 replicate pens. The treatments were as follows: Control diet (CON), $\mathrm{CON}+\mathrm{PHY}$ and $\mathrm{CON}+\mathrm{CPX}$, with $0.5 \%$ or $0.25 \% \mathrm{NaCl}$. The $0.25 \% \mathrm{NaCl}$ versions contained $0.35 \%$ sodium bicarbonate. The $0.5 \%$ salt versions had no sodium bicarbonate. Replicate pen BW, and feed consumption (FC) were measured at 1, 14, and $35 \mathrm{~d}$, and mortality was weighed daily for feed conversion ratio (FCR) calculations. Feed consumption at $14 \mathrm{~d}$ tended to be lower $(p<0.10)$ for $C O N+C P X$ diets compared to $\mathrm{CON}$ and $\mathrm{CON}+\mathrm{PHY}$ diets. The birds fed $\mathrm{CON}+\mathrm{CPX}$ diet consumed less feed but exhibited improved FCR in the presence of $0.5 \% \mathrm{NaCl}$ at $14 \mathrm{~d}$. The birds fed the CON, and CON+PHY diets exhibited higher BW at 14 $d(p<0.05)$ and $35 d(p<0.01)$ of age than did CON+CPX birds. From 15 $d$ to $35 \mathrm{~d}$, birds fed the CON+CPX diet exhibited poorer BW gain (BWG) in the presence of $0.25 \% \mathrm{NaCl}(p<0.05)$. In conclusion, $\mathrm{Cl}$, as $\mathrm{NaCl}$ versus $\mathrm{NaH}_{2} \mathrm{CO}_{3}$, could affect CPX but not PHY feed enzyme function in broilers. Further, it may be suggested that certain feed enzymes may be best utilized at later broiler ages rather than in initial feeds.

\section{INTRODUCTION}

Exogenous enzymes such as phytase, xylanase, amylase, and protease have been extensively scrutinized during the last two decades in studies designed to demonstrate their efficacy in broiler diets. The inclusion of phytase (PHY) has made a significant reduction of inorganic phosphorus in non-ruminant diets possible without compromising live performance, livability, or carcass traits (Adeola et al., 2004; Beudeker et al., 2005; Pieniazek et al., 2017; Scholey et al., 2018; Leyva-Jimenez et al., 2019). Beyond the capacity of PHY to increase the availability of phosphorus via degradation of the anti-nutritive phytate molecule, this enzyme has demonstrated to increase the availability of other minerals as well as protein and starch. Previous researches showed that the addition of PHY to adequate or marginally deficient diets could increase the digestibility coefficients of phosphorus, calcium, amino acids, and metabolizable energy (Selle \& Ravindran, 2007).

The purpose of exogenous dietary carbohydrases has been to digest cell walls to reduce viscosity of the digesta and expose macronutrients to further digestion by endogenous enzymes. This mechanism has been most easily observed in wheat-based diets as the structural and chemical composition of these diets was well suited for maximum efficacy of the enzymes (Yaghobfar et al., 2017). It has also been suggested that a substantial amount of the starch present in feedstuffs such as corn was 
embedded in protein matrixes (García-Lara et al., 2019). This could limit access to critical digestive enzymes such as amylase. To solve these problems carbohydraseprotease cocktails (CPX) have been developed to ensure optimal digestion of all macronutrients in multiple types of diets. In addition, researchers have postulated that exogenous enzyme supplementation could reduce the synthesis of endogenous enzymes, decreasing the energy expenditure of the animal (Mahagna et al., 1995; Yuang et al., 2017). Still, most of the trials performed to assess enzyme effectiveness did not collect data beyond $21 \mathrm{~d}$ of age and, thus, before energy requirements have been generally recognized to increase substantially.

The addition of common table salt $(\mathrm{NaCl})$ to the diet has typically been used to supply the sodium $(\mathrm{Na})$ and chloride $(\mathrm{Cl})$ requirements of birds, which have been estimated by some authors to be $0.28 \% \mathrm{Na}$ and $0.25 \% \mathrm{Cl}$ (Oviedo-Rondón et al. 2001) for birds from 1 to $21 \mathrm{~d}$ of age. Murakami et al. (2001) recommended levels of $0.15 \% \mathrm{Na}$ and $0.23 \% \mathrm{Cl}$ from 22 to $42 \mathrm{~d}$ of age. However, Aviagen (2019) recommends levels of $\mathrm{Na}$ between $0.16-0.23 \%$ and $0.16 \%-0.20 \%$, from $1-24 \mathrm{~d}$ and $25 \mathrm{~d}$ - market age, respectively. Recommended $\mathrm{Cl}$ levels range between $0.16-0.23 \%$ for the whole growing period. It has been established that minerals such as $\mathrm{Na}, \mathrm{Cl}$, and potassium (K) are crucial for nutrient absorption in the intestine (Boron \& Boulpaep, 2016). As a consequence, any imbalance could affect the digestive process due to resulting changes in the digesta $\mathrm{pH}$.

Antinutritive components, such as phytate, have the capacity to reduce ileal availability of $\mathrm{Na}$ by attracting the mineral to the lumen (Ravindran et al., 2006). They suggested that the decrease in $\mathrm{pH}$ due to the presence of high concentrations of phytate could stimulate the secretion of $\mathrm{NaHCO}_{3}$, compromising the mineral availability. Due to the influence of phytate and PHY on $\mathrm{Na}$ availability, researchers have suggested that the dietary electrolyte balance (DEB; $\mathrm{mEq} \mathrm{Na}{ }^{+}+\mathrm{mEq}$ $\mathrm{K}^{+}-\mathrm{mEq} \mathrm{Cl}^{-}$) could interact with the efficacy of the PHY. In a study conducted by Ravindran et al. (2008), it was observed that the addition of PHY to marginally energy-protein deficient diets at low to moderate DEB levels improved broiler performance and availability of nutrients. No benefit of the enzyme was observed at a high DEB level. However, the design of the diets did not permit Ravindran et al. (2008) to determine if the interaction between PHY and DEB was due to the DEB per se, or to the different $\mathrm{Na}$ levels in the diets.

It has been reported that carbohydrases and CPX "cocktails" could improve the digestibility of amino acids and minerals (Kim et al., 2005; Olukosi et al., 2007; Selle et al., 2009; Liu \& Kim, 2017). Absorption of these nutrients could be closely related, not only to the optimal requirement of $\mathrm{Na}$ but also to an optimum ratio between $\mathrm{Na}, \mathrm{K}$, and $\mathrm{Cl}(\mathrm{DEB})$. It is well known that most absorption process of amino acids, sugars, and some minerals, have shown to indirectly depend upon the electrochemical difference between the digesta and the intracellular space of absorptive cells in the intestine (Boron \& Boulpaep, 2016).

The study aimed to determine if the response to $\mathrm{PHY}$ or CPX supplementation on productive performance of broiler was affected by different dietary levels of $\mathrm{Cl}$, produced by different inclusion levels of $\mathrm{NaCl}$ versus $\mathrm{NaHCO}_{3}$ at the same dietary $\mathrm{Na}$.

\section{MATERIALS AND METHODS}

\section{Broiler Progeny Management and Data Collection}

Care for birds in this study was in compliance with the Guide for Care and Use of Agricultural Animals in Research and Teaching (FASS, 2010). Eggs from a resident 60-wk-old Ross 344 x 708SF breeder flock were collected, stored, and incubated under standard conditions. The chicks (average BW at d 1 of $45.51 \mathrm{~g}$ $+0.65 \mathrm{~g}$ ) were hatched, identified by breeder pen (a total of 16) and maintained separately at all times. The chicks were sexed and 32 (2 per breeder pen) male chicks were permanently identified with neck tags and placed in one of 32 floor pens. Each $4.83 \mathrm{~m}^{2}$ pen had 3 feeder trays from $1-7 \mathrm{~d}$. Then 1 tray was removed at $10 \mathrm{~d}$ and $14 \mathrm{~d}$, allowing an appropriate transition from trays to tube feeders. All pen floors were covered with wood shavings, and each pen had one tube feeder and one bell-type drinker, plus a plastic font drinker during the first $7 \mathrm{~d}$. The lighting program during the first $7 \mathrm{~d}$ consisted of $23 \mathrm{~h}$ of light, then $21 \mathrm{~h}$ to 21 $\mathrm{d}$. After $21 \mathrm{~d}$ of age only natural light was employed. Starter feed per bird was equalized to $1.14 \mathrm{~kg}$ per live chick at $7 d$, to ensure equal consumption of nutrients. Grower feed was then added beginning at $14 \mathrm{~d}$ of age. Feeders were shaken twice daily to maintain feed flow from the tubes into the pans. Feed consumption and pen BW were measured at 14 and $35 \mathrm{~d}$, and BWG was calculated by time interval. Mortality was weighed daily and recorded to be included in FCR calculations.

\section{Broiler Dietary Treatments}

The 6 broiler dietary treatments tested were comprised of 2 levels of sodium chloride $(\mathrm{NaCl} ; 0.5$ 
The Effects of Sodium Chloride versus Sodium

Bicarbonate at the Same Dietary Sodium

Concentration on Efficacy of Dietary Phytase and a

Carbohydrase-Protease Cocktail in Broilers

and $0.25 \%)$ that provided two levels of chloride $(\mathrm{Cl}$; 0.43 and $0.28 \%$ ), and three enzyme amendments that included a control (CON), a CON plus phytase enzyme $(\mathrm{CON}+\mathrm{PHY})$, and $\mathrm{CON}$ plus a carbohydrase/protease cocktail (CON+CPX) (Tables 1 and 2). The PHY was assumed to contribute $0.12 \%$ and $0.10 \%$ of available phosphorus (AvP) and calcium (Ca), respectively. To diets with $0.25 \% \mathrm{NaCl}, 0.35 \% \mathrm{NaHCO}_{3}$ was added to equalize the $\mathrm{Na}$ content. Intended differences

Table 1 - Ingredient composition and calculated analysis for broiler dietary treatments for the starter period.

\begin{tabular}{|c|c|c|c|}
\hline \multirow[b]{2}{*}{ Ingredients } & \multicolumn{3}{|c|}{ Basal Dietary Treatment ${ }^{1}$} \\
\hline & CON & $\mathrm{CON}+\mathrm{PHY}$ & $\mathrm{CON}+\mathrm{CPX}$ \\
\hline & \multicolumn{3}{|c|}{ (\%) } \\
\hline Corn & 51.04 & 51.03 & 50.88 \\
\hline Soybean meal (48\% CP) & 25.87 & 25.86 & 25.79 \\
\hline Corn DDGS (26\% CP) & 10.60 & 10.80 & 10.60 \\
\hline Poultry by-product meal & 4.48 & 4.40 & 4.55 \\
\hline Poultry Fat & 3.32 & 3.32 & 3.39 \\
\hline Sodium chloride ${ }^{1}$ & - & - & - \\
\hline Sodium bicarbonate ${ }^{1}$ & - & - & - \\
\hline Limestone & 0.88 & 1.05 & 0.88 \\
\hline Dicalcium phosphate & 2.22 & 1.47 & 2.22 \\
\hline Premixes $^{2}$ & 0.60 & 0.60 & 0.60 \\
\hline Filler (sand) & 0.05 & 0.50 & 0.05 \\
\hline Phytase premix ${ }^{3}$ & 0.00 & 0.03 & 0.00 \\
\hline Avizyme $1502^{4}$ & 0.00 & 0.00 & 0.10 \\
\hline L-Lysine & 0.11 & 0.11 & 0.11 \\
\hline DL-Methionine & 0.15 & 0.15 & 0.15 \\
\hline \multirow[t]{2}{*}{ L-Threonine } & 0.09 & 0.09 & 0.09 \\
\hline & 100.00 & 100.00 & 100.00 \\
\hline \multicolumn{4}{|l|}{ Calculated nutrients ${ }^{5}$} \\
\hline $\mathrm{ME}(\mathrm{kcal} / \mathrm{g})$ & 2.80 & 2.80 & 2.80 \\
\hline Crude protein & 23.00 & 23.00 & 23.00 \\
\hline Lysine & 1.26 & 1.26 & 1.26 \\
\hline Methionine + Cysteine & 0.91 & 0.91 & 0.91 \\
\hline Threonine & 0.84 & 0.84 & 0.84 \\
\hline Calcium & 0.90 & $0.90^{4}$ & 0.90 \\
\hline Available phosphorus & 0.45 & $0.45^{4}$ & 0.45 \\
\hline Sodium & 0.21 & 0.21 & 0.21 \\
\hline
\end{tabular}

'The were six dietary treatments consisted of: $\mathrm{CON}=\mathrm{Control}, \mathrm{CON}+\mathrm{PHY}=\mathrm{CON}$ plus $500 \mathrm{FTU} / \mathrm{kg}$ feed (Phyzyme XP), and CON+CPX $=$ CON plus $0.1 \%$ inclusion of Avizyme 1502 , with $0.5 \%$ or $0.25 \% \mathrm{NaCl}$. The $0.25 \% \mathrm{NaCl}$ versions contained $0.35 \%$ sodium bicarbonate. The $0.5 \%$ salt versions had no sodium bicarbonate.

2Premixes provided the following (per $\mathrm{kg}$ of diet): vitamin $\mathrm{A}, 6600 \mathrm{IU}$; vitamin $\mathrm{D}_{3}$, 2,000 IU; vitamin E, $33 \mathrm{IU}$; vitamin $\mathrm{B}_{12}, 19.8 \mu \mathrm{g}$; riboflavin, $6.6 \mathrm{mg}$; niacin, $55 \mathrm{mg}$; D-pantothenate, $11 \mathrm{mg}$; menadione $\left(\mathrm{K}_{3}\right), 4 \mathrm{mg}$; folic acid, $1.1 \mathrm{mg}$; thiamine, $2 \mathrm{mg}$; pyridoxine, $4 \mathrm{mg}$; D-biotin, $126 \mu$; selenium (as $\mathrm{Na}_{2} \mathrm{SeO}_{3}$ ), $0.15 \mathrm{mg}$; manganese, 60 $\mathrm{mg}$; zinc, $60 \mathrm{mg}$; iron, $40 \mathrm{mg}$; copper, $5 \mathrm{mg}$; iodine, $1.3 \mathrm{mg}$; cobalt, $0.5 \mathrm{mg}$; choline chloride, $600 \mathrm{mg}$; monensin, $99.21 \mathrm{mg}$.

3Phyzyme XP TPT (Dupont Animal Nutrition, Marlborough, UK), an Escherichia coli-derived phytase, was added at $500 \mathrm{FTU} / \mathrm{kg}$ to replace $0.12 \%$ available phosphorus (AvP) and $0.1 \%$ calcium (Ca).

${ }^{4}$ Avizyme 1502 (Dupont Animal Nutrition, Marlborough, UK), is composed of xylanase (300 U/kg), Trichoderma longibrachiatum, protease (4000 U/kg), Bacillus subtilis and amylase (400 U/kg), and Bacillus amyloliquofaciens.

${ }^{5}$ The nutrient compositions were calculated from proximate analyses of all ingredients, and final diet composition was confirmed by proximate analyses. in mineral content of the diets were confirmed by analyses. Birds were provided feed for ad libitum consumption with starter feed offered as crumbles, while grower feed was in pellet form. All the treatment diets were made from common batches of ingredients and were corn-soybean meal based with $10-10.9 \%$ corn distiller's dried grains with solubles (DDGS), 4 $4.5 \%$ poultry by-product meal (PBM), and formulated to be isonitrogenous with similar amino acid levels.

Table 2 - Ingredient composition and calculated analysis for broiler dietary treatments for the grower period.

\begin{tabular}{|c|c|c|c|}
\hline \multirow[b]{2}{*}{ Ingredients } & \multicolumn{3}{|c|}{ Basal Dietary Treatment ${ }^{1}$} \\
\hline & CON & $\mathrm{CON}+\mathrm{PHY}$ & $\mathrm{CON}+\mathrm{CPX}$ \\
\hline & \multicolumn{3}{|c|}{$(\%)$} \\
\hline Corn & 55.17 & 55.17 & 55.17 \\
\hline Soybean meal (48\% CP) & 18.96 & 18.96 & 18.96 \\
\hline Corn DDGS (26\% CP) & 10.00 & 10.00 & 10.00 \\
\hline Poultry by-product meal & 4.40 & 4.40 & 4.40 \\
\hline Poultry Fat & 5.00 & 5.00 & 5.00 \\
\hline Sodium chloride ${ }^{1}$ & - & - & - \\
\hline Sodium bicarbonate ${ }^{1}$ & - & - & - \\
\hline Limestone & 0.92 & 1.09 & 0.92 \\
\hline Dicalcium phosphate & 2.01 & 1.27 & 2.01 \\
\hline Premixes $^{2}$ & 0.60 & 0.60 & 0.60 \\
\hline Filler (sand) & 1.67 & 2.21 & 1.57 \\
\hline Phytase premix ${ }^{3}$ & 0.00 & 0.03 & 0.00 \\
\hline Avizyme $1502^{4}$ & 0.00 & 0.00 & 0.10 \\
\hline L-Lysine & 0.30 & 0.30 & 0.30 \\
\hline DL-Methionine & 0.20 & 0.20 & 0.20 \\
\hline \multirow[t]{2}{*}{ L-Threonine } & 0.16 & 0.16 & 0.16 \\
\hline & 100.00 & 100.00 & 100.00 \\
\hline \multicolumn{4}{|l|}{ Calculated nutrients $^{5}$} \\
\hline ME (kcal/g) & 2.90 & 2.90 & 2.90 \\
\hline Crude protein & 20.00 & 20.00 & 20.00 \\
\hline Lysine & 1.20 & 1.20 & 1.20 \\
\hline Methionine + Cysteine & 0.86 & 0.86 & 0.86 \\
\hline Threonine & 0.80 & 0.80 & 0.80 \\
\hline Calcium & 0.85 & $0.85^{4}$ & 0.85 \\
\hline Available phosphorus & 0.40 & $0.40^{4}$ & 0.40 \\
\hline Sodium & 0.21 & 0.21 & 0.21 \\
\hline
\end{tabular}

The were six dietary treatments consisted of $\mathrm{CON}=\mathrm{Control}, \mathrm{CON}+\mathrm{PHY}=\mathrm{CON}$ plus $500 \mathrm{FTU} / \mathrm{kg}$ feed (Phyzyme XP), and CON+CPX $=$ CON plus $0.1 \%$ inclusion of Avizyme 1502 , with $0.5 \%$ or $0.25 \% \mathrm{NaCl}$. The $0.25 \% \mathrm{NaCl}$ versions contained $0.35 \%$ sodium bicarbonate. The $0.5 \%$ salt versions had no sodium bicarbonate.

2Premixes provided the following (per $\mathrm{kg}$ of diet): vitamin $\mathrm{A}, 6600 \mathrm{IU}$; vitamin $\mathrm{D}_{3^{\prime}}$ 2,000 IU; vitamin E, $33 \mathrm{IU}$; vitamin $\mathrm{B}_{12}, 19.8 \mu \mathrm{g}$; riboflavin, $6.6 \mathrm{mg}$; niacin, $55 \mathrm{mg}$; D-pantothenate, $11 \mathrm{mg}$; menadione $\left(K_{3}\right), 4 \mathrm{mg}$; folic acid, $1.1 \mathrm{mg}$; thiamine, $2 \mathrm{mg}$; pyridoxine, $4 \mathrm{mg}$; D-biotin, $126 \mu \mathrm{g}$; selenium (as $\mathrm{Na}_{2} \mathrm{SeO}_{3}$ ), $0.15 \mathrm{mg}$; manganese, 60 mg; zinc, $60 \mathrm{mg}$; iron, $40 \mathrm{mg}$; copper, $5 \mathrm{mg}$; iodine, $1.3 \mathrm{mg}$; cobalt, $0.5 \mathrm{mg}$; choline chloride, 600 mg; monensin, $99.21 \mathrm{mg}$.

${ }^{3}$ Phyzyme XP TPT (Dupont Animal Nutrition, Marlborough, UK), an Escherichia coli-derived phytase, was added at $500 \mathrm{FTU} / \mathrm{kg}$ to replace $0.12 \%$ available phosphorus (AvP) and $0.1 \%$ calcium (Ca).

${ }^{4}$ Avizyme 1502 (Dupont Animal Nutrition, Marlborough, UK), is composed of xylanase (300 U/kg), Trichoderma longibrachiatum, protease (4000 U/kg), Bacillus subtilis and amylase (400 U/kg), and Bacillus amyloliquofaciens.

${ }^{5}$ The nutrient compositions were calculated from proximate analyses of all ingredients, and final diet composition was confirmed by proximate analyses. 
The phytase enzyme product (PHY) (Phyzyme XP TPT, Dupont Animal Nutrition, Marlborough, UK), an Escherichia coli-derived phytase, was added at $500 \mathrm{FTU} /$ $\mathrm{kg}$. The CPX enzyme cocktail (Avizyme 1502, Dupont Animal Nutrition, Marlborough, UK), provided 300 $\mathrm{U}$ of xylanase/kg from Trichoderma longibrachiatum, $4000 \mathrm{U}$ of protease from Bacillus subtilis, and $400 \mathrm{U}$ of amylase from Bacillus amyloliquofaciens. Enzyme activity assays of finisher feed were performed by the enzyme manufacturer, and the expected activity for each enzyme was confirmed.

\section{Statistical Methods}

A randomized complete block design with a 2 x 3 factorial arrangement of treatments was used (dietary enzyme $\times \mathrm{NaCl}$ level) with the general linear model of SAS (SAS Institute, 2008) used to analyze live performance. Variable means were partitioned by LSMEANS and were considered statistically different when $p<0.05$, while $p<0.10$ was considered to be numerical trends.

\section{RESULTS}

The effects of dietary treatments on broiler BW, BWG, FC, FCR, and mortality at 14 and $35 \mathrm{~d}$ of age are shown in Table 3. Even when no main effects were found for $F C$ and $F C R$, interactions were detected $(p<0.05)$ for FC (Figure 1) and FCR (Figure 2) at $14 \mathrm{~d}$. Feeding $C O N+C P X$ in the presence of $0.5 \% \mathrm{NaCl}$ decreased $\mathrm{FC}$, but improved FCR at 14 $\mathrm{d}$. No differences in FC were observed after $14 \mathrm{~d}$. At $14 d(p<0.05)$ and $35 d(p<0.05)$ broilers fed CON and $\mathrm{CON}+\mathrm{PHY}$ diets exhibited greater BW and BWG than the birds fed the CON+CPX diet. However, a significant interaction was detected were broilers fed CON+CPX diets with $0.25 \% \mathrm{NaCl}$ exhibited reduced BW at $35 \mathrm{~d}(p<0.05$; Figure 3$)$ as compared to CON and $\mathrm{CON}+\mathrm{PHY}$. At $35 \mathrm{~d}$ an interaction was observed that demonstrated that BWG $(p<0.05$; Figure 4) of broilers fed $\mathrm{CON}+\mathrm{CPX}$ was greater when the diet contained $0.5 \% \mathrm{NaCl}$. None of the dietary factors studied affected mortality (Table 3).

Table 3 - Effect of dietary treatment on broiler body weight (BW), body weight gain (BWG), feed consumption (FC), feed conversion ratio (FCR), and mortality.

\begin{tabular}{|c|c|c|c|c|c|c|c|c|c|c|c|}
\hline \multirow{3}{*}{ Variable } & \multirow{3}{*}{ Age (d) } & \multicolumn{7}{|c|}{ Treatment $^{1}$} & \multicolumn{3}{|c|}{ Source of variability } \\
\hline & & \multicolumn{3}{|c|}{ Diet } & & \multicolumn{2}{|c|}{$\mathrm{NaCl}$ level } & \multirow{3}{*}{$\mathrm{SEM}^{3}$} & \multirow{2}{*}{\multicolumn{2}{|c|}{$\begin{array}{ll} & \mathrm{NaCl} \\
\text { iet } & \text { Level } \\
\end{array}$}} & \multirow{2}{*}{$\begin{array}{l}\text { Diet } x \\
\mathrm{NaCl}\end{array}$} \\
\hline & & $\mathrm{CON}$ & $\mathrm{CON}+\mathrm{PHY}$ & $\mathrm{CON}+\mathrm{CPX}$ & $\mathrm{SEM}^{2}$ & $0.5 \%$ & $0.25 \%$ & & & & \\
\hline & & \multicolumn{6}{|c|}{ (g) } & & \multicolumn{3}{|c|}{ (p-value) } \\
\hline \multirow[t]{3}{*}{ BW } & 1 & 46 & 46 & 45 & 0.2 & 45 & 46 & 0.2 & NS & NS & NS \\
\hline & 14 & $521^{a}$ & $520^{a}$ & $506^{b}$ & 4.7 & 518 & 513 & 3 & $<0.05$ & NS & NS \\
\hline & 35 & $2531^{\mathrm{A}}$ & $2533^{A}$ & $2481^{B}$ & 12.0 & 2520 & 2509 & 9 & $<0.01$ & NS & $<0.05$ \\
\hline \multirow[t]{3}{*}{ BWG } & $1-14$ & $476^{a}$ & $475^{a}$ & $460^{b}$ & 4.7 & 472 & 468 & 3 & $<0.05$ & NS & NS \\
\hline & $15-35$ & $2009^{a}$ & $2012^{a}$ & $1976^{b}$ & 10.0 & 2003 & 1995 & 8 & $<0.05$ & NS & $<0.05$ \\
\hline & $1-35$ & $2485^{a}$ & $2487^{a}$ & $2436^{b}$ & 13.43 & 2475 & 2464 & 11 & $<0.05$ & NS & NS \\
\hline \multirow[t]{4}{*}{ FC } & $1-14$ & $710^{x}$ & $711^{x}$ & $675^{y}$ & 12.0 & 697 & 700 & 6 & $<0.10$ & NS & $<0.05$ \\
\hline & $15-35$ & 2672 & 2676 & 2774 & 69.0 & 2662 & 2753 & 50 & NS & NS & NS \\
\hline & $1-35$ & 3388 & 3377 & 3446 & 72.66 & 3361 & 3447 & 59 & NS & NS & NS \\
\hline & \multicolumn{11}{|c|}{ (g:g) } \\
\hline \multirow[t]{3}{*}{$\mathrm{FCR}^{4}$} & $1-14$ & 1.49 & 1.49 & 1.46 & 0.02 & 1.46 & 1.49 & 0.02 & NS & NS & $<0.05$ \\
\hline & $15-35$ & 1.69 & 1.69 & 1.75 & 0.04 & 1.69 & 1.73 & 0.03 & NS & NS & NS \\
\hline & $1-35$ & 1.65 & 1.65 & 1.71 & 0.04 & 1.65 & 1.69 & 0.03 & NS & NS & NS \\
\hline \multicolumn{12}{|c|}{ (\%) } \\
\hline \multirow[t]{2}{*}{ Mortality } & $1-14$ & 1.56 & 1.56 & 1.71 & 0.65 & 1.82 & 1.04 & 0.59 & NS & NS & NS \\
\hline & $1-35$ & 2.34 & 2.73 & 3.13 & 1.31 & 3.65 & 1.83 & 1.07 & NS & NS & NS \\
\hline
\end{tabular}

A, B Means across columns lacking a common superscript are significantly different at the $p<0.01$.

$\mathrm{a}, \mathrm{b}$ Means across columns lacking a common superscript are significantly different at the $p<0.05$.

$x, y$ Means across columns lacking a common superscript are significantly different at the $p<0.10$.

${ }^{1}$ The were six dietary treatments consisted of CON = Control, CON+PHY = CON plus 500 FTU/kg feed (Phyzyme XP), and CON+CPX $=$ CON plus 0.1\% inclusion of Avizyme 1502 , with $0.5 \%$ or $0.25 \% \mathrm{NaCl}$. The $0.25 \% \mathrm{NaCl}$ versions contained $0.35 \%$ sodium bicarbonate. The $0.5 \%$ salt versions had no sodium bicarbonate.

${ }^{2} \mathrm{SEM}$ for $\mathrm{n}=8$ pens.

${ }^{3}$ SEM for $n=12$ pens.

${ }^{4} \mathrm{FCR}$ included BW of mortality 


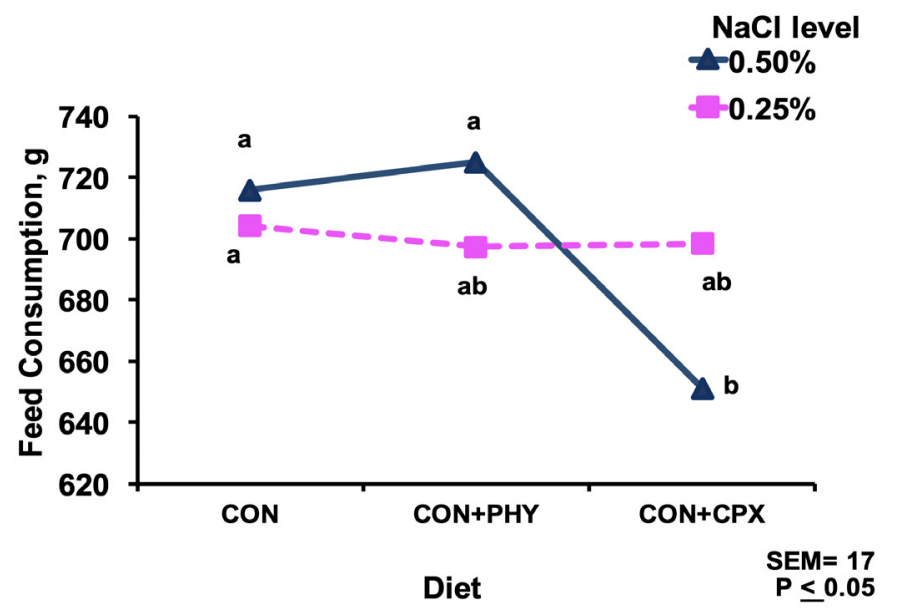

Figure 1 - Effect of dietary treatment on broiler feed consumption from 1 to $14 \mathrm{~d}$ of age. The six dietary treatments consisted of $\mathrm{CON}=\mathrm{Control}, \mathrm{CON}+\mathrm{PHY}=\mathrm{CON}$ plus 500 FTU $/ \mathrm{kg}$ feed (Phyzyme XP), and CON+CPX $=$ CON plus $0.1 \%$ inclusion of Avizyme 1502, with $0.5 \%$ or $0.25 \% \mathrm{NaCl}$. The $0.25 \% \mathrm{NaCl}$ (square) diets contained $0.35 \%$ sodium bicarbonate. The $0.5 \%$ salt (diamond) diets had no sodium bicarbonate. Pooled standard error of the mean (SEM) for $n=24$ pens. Means lacking a common superscript are significantly different at $p<0.05$.

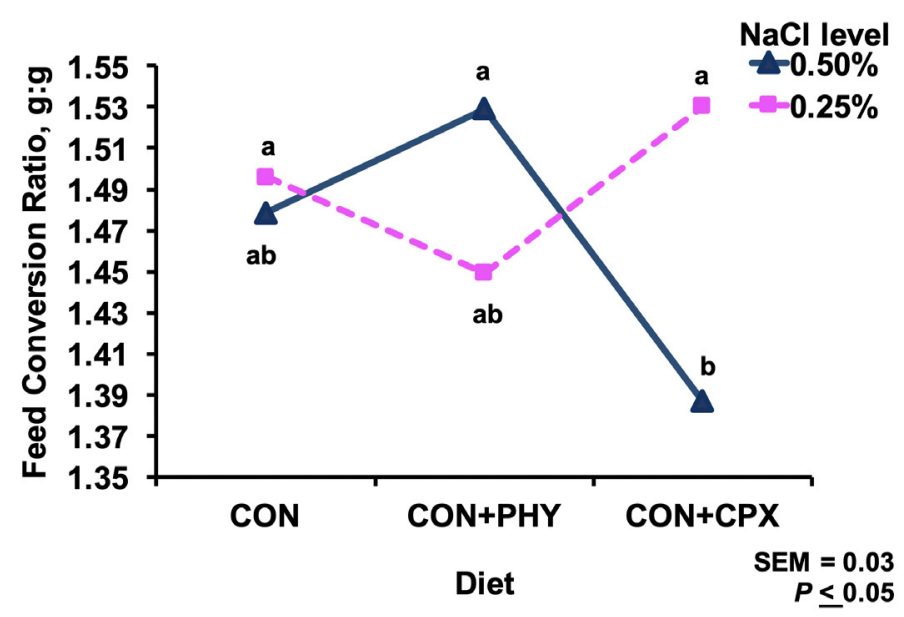

Figure 2 - Effect of dietary treatment on broiler adjusted feed conversion ratio from 1 to $14 \mathrm{~d}$ of age. The six dietary treatments consisted of $\mathrm{CON}=\mathrm{Control}, \mathrm{CON}+\mathrm{PHY}=\mathrm{CON}$ plus $500 \mathrm{FTU} / \mathrm{kg}$ feed (Phyzyme XP), and CON+CPX $=$ CON plus $0.1 \%$ inclusion of Avizyme 1502 , with $0.5 \%$ or $0.25 \% \mathrm{NaCl}$. The $0.25 \% \mathrm{NaCl}$ (square) diets contained $0.35 \%$ sodium bicarbonate. The $0.5 \%$ salt (diamond) diets had no sodium bicarbonate. Pooled standard error of the mean (SEM) for $n=24$ pens. Means lacking a common superscript are significantly different at $p<0.05$.

\section{DISCUSSION}

This study determined the effects of the addition of PHY or CPX to a corn-soybean meal-DDGS-PBM based diet formulated with two different levels of $\mathrm{Cl}$ created by amending basal diets with either $\mathrm{NaCl}$ or $\mathrm{NaHCO}_{3}$ on broiler live performance to $35 \mathrm{~d}$ of age. In this experiment, a marginally low level of dietary ME and commercially typical levels of AvP and Ca for CON and $\mathrm{CON}+\mathrm{CPX}$ diets (Tables 1 and 2) were used. Only in the $\mathrm{CON}+\mathrm{PHY}$ diets were AvP and $\mathrm{Ca}$ reduced by $0.12 \%$ and $0.10 \%$, respectively, expecting the PHY to compensate for these reductions. Also, $\mathrm{Na}$ and $\mathrm{K}$

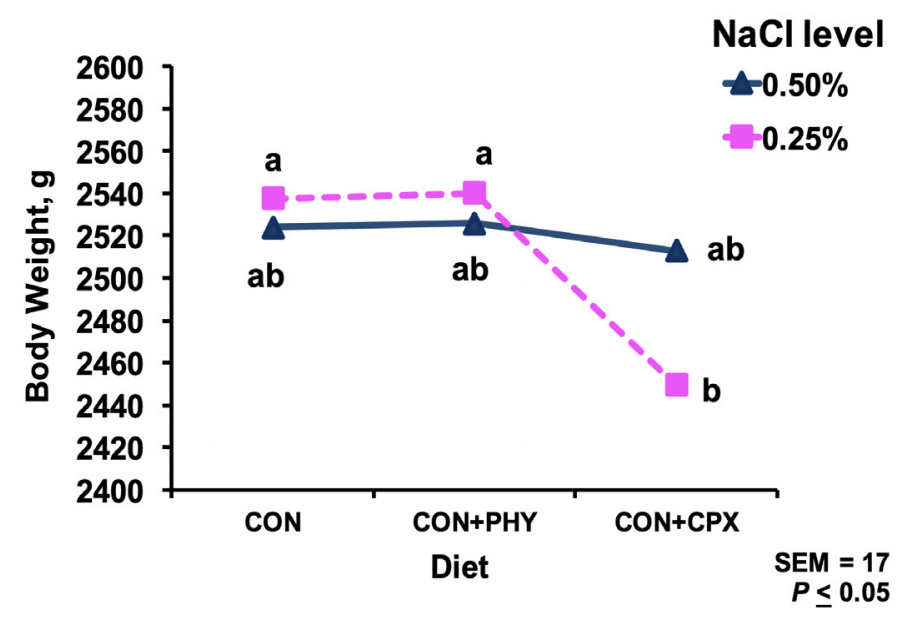

Figure 3 - Effect of dietary treatment on broiler BW at $35 \mathrm{~d}$ of age. The six dietary treatments consisted of $\mathrm{CON}=$ Control, $\mathrm{CON}+\mathrm{PHY}=\mathrm{CON}$ plus $500 \mathrm{FTU} / \mathrm{kg}$ feed (Phyzyme $X P)$, and $\mathrm{CON}+\mathrm{CPX}=\mathrm{CON}$ plus $0.1 \%$ inclusion of Avizyme 1502 , with $0.5 \%$ or $0.25 \%$ $\mathrm{NaCl}$. The $0.25 \% \mathrm{NaCl}$ (square) diets contained $0.35 \%$ sodium bicarbonate. The $0.5 \%$ salt (diamond) diets had no sodium bicarbonate. Pooled standard error of the mean (SEM) for $n=24$ pens. Means lacking a common superscript are significantly different at $p<0.05$.

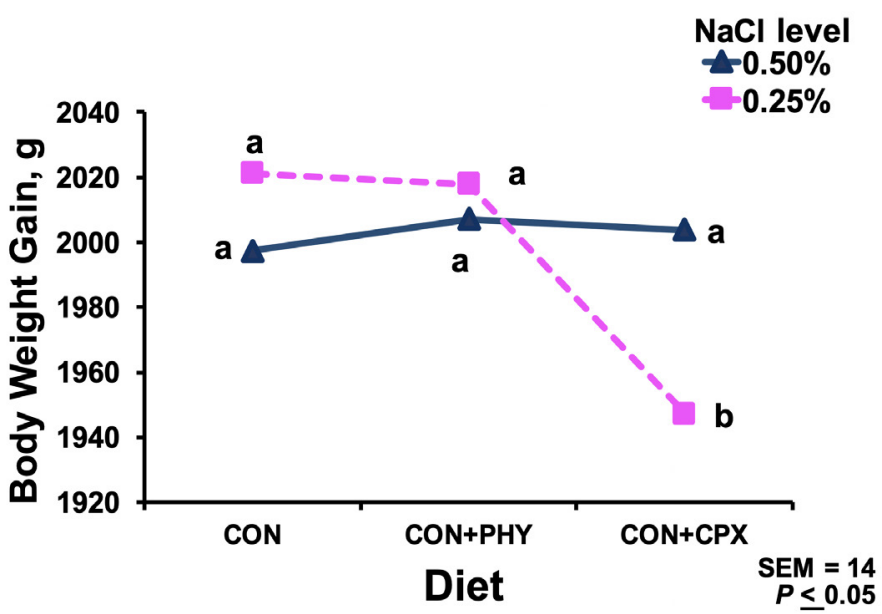

Figure 4 - Effect of dietary treatment on broiler BW gain from 15 to $35 \mathrm{~d}$ of age. The six dietary treatments consisted of $\mathrm{CON}=\mathrm{Control}, \mathrm{CON}+\mathrm{PHY}=\mathrm{CON}$ plus $500 \mathrm{FTU} / \mathrm{kg}$ feed (Phyzyme XP), and CON+CPX = CON plus $0.1 \%$ inclusion of Avizyme 1502, with $0.5 \%$ or $0.25 \% \mathrm{NaCl}$. The $0.25 \% \mathrm{NaCl}$ (square) diets contained $0.35 \%$ sodium bicarbonate. The $0.5 \%$ salt (diamond) diets had no sodium bicarbonate. Pooled standard error of the mean (SEM) for $n=24$ pens. Means lacking a common superscript are significantly different at $p<0.05$.

were the same for all the diets $(0.22 \%$ and $0.69 \%$, respectively) as all feeds were made from a common basal, and only $\mathrm{Cl}$ differed, being $0.40 \%$ and $0.25 \%$ for the $0.50 \%$ and $0.25 \% \mathrm{NaCl}$ diets, respectively.

Broilers fed the CON+PHY diet maintained live performance similar to the CON diet, which demonstrated that the PHY enzyme restored AvP and Ca to normal levels as reported by others (Donato et al., 2013; dos Santos et al., 2017; Walk \& F. Poernama, 2018). However, no other nutritional benefits due to the PHY were observed. Calculated electrolyte balance (DEB) for the $0.50 \% \mathrm{NaCl}$ level diets was $164 \mathrm{mEq} / \mathrm{kg}$, contrasting with the $203 \mathrm{mEq} / \mathrm{kg}$ of the $0.25 \% \mathrm{NaCl}$ 
diet, with only $\mathrm{Cl}$ being different. By way of comparison, Ravindran et al. (2008) studied the effect of DEB and the addition of phytase to marginally deficient nonphytate phosphorus and Ca diets. Four DEB levels of $150,225,300$, and $375 \mathrm{mEq} / \mathrm{kg}$ (or $0.15,0.18,0.35$, and $0.52 \% \mathrm{Na}$, respectively) and two levels of phytase ( 0 and $500 \mathrm{FTU} / \mathrm{kg}$ ) were studied. They reported that FCR was improved when phytase was added to lower DEB diets (150 - $300 \mathrm{mEq}$ ), but not to the $375 \mathrm{mEq} / \mathrm{kg}$ diet. However, they could not determine if this response was because of the DEB or due to the differences in the $\mathrm{Na}$ level of the different diets. Nonetheless, they attributed the response at $375 \mathrm{mEq}$ to an excess in $\mathrm{Na}$ $(0.52 \%)$ that negatively affected nutrient absorption and metabolism.

Broilers fed CON+CPX grew more slowly than CON and CON+PHY birds during both 1-14 $\mathrm{d}$ and 15$35 \mathrm{~d}$ periods ( $p<0.05$; Table 3$)$. The reduced growth rate could be partially explained by a trend observed in which FC during the 1-14 $\mathrm{d}$ age period for the $\mathrm{CON}+\mathrm{CPX}$ diet tended to be lower compared to the other two treatments $(p<0.10$; Table 3$)$. However, the interaction of diet $\times \mathrm{NaCl}$ level (Figure 1) demonstrated that broilers fed the CON+CPX diet at the 0.5\% $\mathrm{NaCl}$ level consumed numerically less feed, albeit at an improved FCR ( $p<0.05$; Figure 2$)$ probably due to the lower maintenance required for their reduced BW, than the broilers fed the same diet at the 0.25\% $\mathrm{NaCl}$ level. Thus, the initially reduced FC observed with the CPX supplementation (Figure 1) was apparently ameliorated by the replacement of $\mathrm{NaCl}$ by $\mathrm{NaHCO}_{3}$ but reduced BWG and BW $(p<0.05)$ persisted to $35 \mathrm{~d}$ (Table 3). Previous researches in various animal species demonstrated that the addition of $\mathrm{NaHCO}_{3}$ increased FC (Tripathi et al., 2004; Yoruk et al., 2004ab; Ahmad et al., 2006). However, the consistency of this effect has been debated by others (Fuentes et al., 1998; Balnave et al., 1999; Zakaria et al., 2008) as a multiple dietary factor and physiology of the animal could have modifying effects. Indeed, this effect was only observed during the 1-14 $d$ period of the present study.

Even though CON+CPX diets exhibited statistically similar responses in terms of $\mathrm{FC}$ relative to the differences in dietary $\mathrm{NaCl}$ versus $\mathrm{NaHCO}_{3}$ (Figure 1), it seemed that the addition of CPX tended to reduce FC prior to $14 \mathrm{~d}(p<0.10$; Table 3) primarily in the presence of $0.5 \% \mathrm{NaCl}$ when compared to the CON diet (Figure 1) Interestingly, although broilers fed the CON diet continued to exhibit greater BWG than $\mathrm{CON}+\mathrm{CPX}$ fed birds from 15 to $35 \mathrm{~d}(p<0.05$; Table 3$)$, the diet $x \mathrm{NaCl}$ interaction for BWG ( $p<0.05$; Figure 3$)$ demonstrated that it was only the CON+CPX birds receiving $0.25 \%$
$\mathrm{NaCl}$ that did not grow normally. Thus, it was evident that $\mathrm{Cl}$ was interacting with some component of the CPX enzyme cocktail as dietary $\mathrm{Cl}$ had no effect in the CON or CON+PHY diets. Buonocore et al. (1977) originally characterized the chicken pancreatic $\alpha$-amylase and described it as a $\mathrm{Ca}^{+2}$ glycoprotein. Calcium was necessary for the structural stability of the enzyme while $\mathrm{Cl}$ was an activator, which was also true for amylases in general because they have very well conserved three-dimensional structure among species including mammals, other birds, insects, and some bacteria (D'Amico et al., 2000). On the other hand, $\alpha$-amylase from most bacteria has been reported to be Ca-dependent but Cl-independent (Machius et al., 1998; Mehta and Satyanarayana, 2016) as the amylase that was present in CPX.

The inclusion of exogenous enzymes such as alphaamylase at an early age has led to down-regulation and reduced excretion of potentially essential endogenous enzymes associated with a reduced pancreas weight (Mahagna et al., 1995; Gracia et al., 2003; Onderci et al., 2006). Furthermore, Jiang et al. (2008) found that supplementation with alpha amylase to broiler diets negatively affected mRNA expression pancreatic amylase. On the other hand, Yuan et al. (2017) demonstrated that the inclusion of bacterial amylases not only affected the activity of disaccharidases in the small intestine but also reduced the mRNA expression of sodium/glucose cotransporter 1 (SGLT 1) in the duodenum and jejunum. Such an effect may have modulated digestive physiology. We could hypothesize that the downregulation or reduction of endogenous amylase and SGLT1 (in addition to the fact that there could be a lower $\mathrm{Cl}$ level available for the endogenous amylase activation) would result in reduced digestion of starch and absorption of glucose, affecting BW and BWG.

It appeared that the ME that was expected to come from the addition of CPX (mainly from carbohydrates) was not apparent, which could have been due to dietary $\mathrm{Cl}$. Dietary $\mathrm{NaCl}$ has also been demonstrated to affect intestinal amino acid absorption (Chen et al., 2005), which could have been related to some additional interaction with the protease in the CPX enzyme cocktail.

Cowieson \& Ravindran (2008) fed male broilers in cages to $21 \mathrm{~d}$ either a nutritionally adequate diet or a marginally ME and amino acid-deficient diet with or without CPX in a $2 \times 2$ factorial design. They reported that BWG and FCR were improved by the addition of the CPX enzyme cocktail, something that 
was not observed in the present experiment. However, Cowieson \& Ravindran (2008) fed mash diets, which were $30 \%$ lower in total phosphorus and 20\% lower in $\mathrm{NaCl}$ than the present $0.5 \% \mathrm{NaCl}$ diet. It was important to point out that the ME in the present CON starter and grower diets were 181 and $121 \mathrm{kcal} / \mathrm{kg}$, respectively, less than those of Cowieson \& Ravindran (2008). In addition, the present diets contained approximately $9 \%$ less corn, limiting the availability of substrate upon which certain enzymes could work. This supported the concept that the effectiveness of feed enzymes could depend upon many factors in the diet and animal digestive tract (Bedford, 2018). It was concluded that dietary $\mathrm{Cl}$, as $\mathrm{NaCl}$ versus $\mathrm{NaH}_{2} \mathrm{CO}_{3}$, could affect CPX but not PHY feed enzyme function in broilers. Further, it may be suggested that certain feed enzymes may be best utilized at later broiler ages rather than in initial feeds.

\section{REFERENCES}

Adeola O, Sands JS, Onyango, EM, Dilger RN. Evaluation of microbial phytase in broiler diets. Poultry Science 2004;83:962-970.

Ahmad T, Mushtaq T, Mahr-Un-Nisa, Sarwarb M, Hoogec DM, Mirzaa MA. Effect of different non-chloride sodium sources on the performance of heat-stressed broiler chickens. British Poultry Science 2006;47:249256.

Aviagen. Ross Broiler: nutrition specifications. 2019. Available from: http://tmea.aviagen.com/assets/Tech_Center/Ross_Broiler/ RossBroilerNutritionSpecs2019-EN.pdf

Balnave D, Hayat J, Brake J. Sodium bicarbonate and potassium bicarbonate supplements for broilers can cause poor performance at high temperature. British Poultry Science 1999;40:411-418.

Bedford MR. The evolution and application of enzymes in the animal feed industry: the role of data interpretation. British Poultry Science 2018;59:486-493.

Beudeker RF, Simons PCM, Versteegh HAJ, Verschoor GJ, Slump P, Kemme PA, et al. Improvement of phosphorus availability by microbial phytase in broilers and pigs. British Journal of Nutrition 2005;93:137-152.

Boron WF, Boulpaep EL. Medical physiology: a cellular and molecular approach. $3^{\text {rd }}$ ed. Philadelphia: Elsevier; 2016.

Buonocore V, Deponte R, Gramenzi F, Petrucci T, Poerio E, Silano V. Purification and properties of a-amylase from chicken (Gallus gallus I.) pancreas. Molecular and Cellular Biochemistry 1997;17:11-16.

Chen J, Li X, Balnave D, Brake J. The influence of dietary sodium chloride, arginine:lysine ratio, and methionine source on apparent ileal digestibility of arginine and lysine in acutely heat-stressed broilers. Poultry Science 2005;84:294-297.

Cowieson AJ, Ravindran V. Effect of exogenous enzymes in maize-based diets varying in nutrient density for young broilers: growth performance and digestibility of energy, minerals, and amino acids. British Poultry Science 2008;49:37-44.

D'Amico S, Gerday C, Feller G. Structural similarities and evolutionary relationships in chloride-dependent a-amylases. Gene 2000;253:95105.
Donato DCZ, Ribeiro PAP, Magalhães, JD, Polycarpo, GV, Garcia, PDSR Burbarelli, MFC, et al. Nutritional balance of broilers fed diets containing two calcium levels and supplemented with different phytase levels. Brazilian Journal of Poultry Science 2013;15:353-363.

Dos Santos TT, Masey O’Neill HV, González-Ortiz G, Camacho-Fernández D, López-Coello C. Xylanase, protease and superdosing phytase interactions in broiler performance, carcass yield and digesta transit time. Animal Nutrition 2017;3:121-126.

FASS. Guide for the care and use of agricultural animals in research and teaching. $3^{\text {rd }}$ ed. Champaign: Federation of Animal Science Society; 2010.

Fuentes MF, Zapata JF, Espindola GB, Freitas ER, Santos MG, Sousa FM. Sodium bicarbonate supplementation in diets for guinea fowl raised at high environmental temperatures. Poultry Science 1998;77:714-717.

García-Lara S, Chuck-Hernandez C, Serna-Saldivar SO. Development and structure of the corn kernel. In: Serna-Sladivar SO, editor. Corn: chemistry and technology. $3^{\text {rd }}$ ed. Amsterdam: Elsevier; 2019. p.147163.

Gracia MI, Araníbar MJ, Lázaro R, Medel P, Mateos GG. a-Amylase supplementation of broiler diets based on corn. Poultry Science 2003;82:436-442.

Jiang Z, Zhou Y, Lu F, Han Z, Wang T. Effects of different levels of supplementary alpha-amylase on digestive enzyme activities and pancreatic amylase mrna expression of young broilers. AsianAustralasian Journal of Animal Science 2008:21:97-102

Kim JC, Simmins PH, Mullan BP, Pluske JR. The effect of wheat phosphorus content and supplemental enzymes on digestibility and growth performance of weaner pigs. Animal Feed Science and Technology 2005;118:139-152.

Leyva-Jimenez H, Alsadwi AM, Gardner K, Voltura E, Bailey CA. Evaluation of high dietary phytase supplementation on performance, bone mineralization, and apparent ileal digestible energy of growing broilers. Poultry Science 2019;98:811-819.

Liu W, Kim I. Effects of dietary xylanase supplementation on performance and functional digestive parameters in broilers fed wheat-based diets. Poultry Science 2017;96:566-573.

Machius M, Declerck N, Huber R, Wiegand G. Activation of Bacillus licheniformis $\alpha$-amylase through a disorder $\rightarrow$ order transition of the substrate-binding site mediated by a calcium-sodium-calcium metal triad. Structure 1998;6:281-292

Mahagna M, Nir I, Larbier M, Nitsan Z. Effect of age and exogenous amylase and protease on development of the digestive tract, pancreatic enzyme activities and digestibility of nutrients in young meat-type chicks. Reproduction, Nutrition, Development 1995;35:201-212.

Mehta D, Satyanarayana T. Bacterial and archaeal $\alpha$-amylases: diversity and amelioration of the desirable characteristics for industrial applications. Frontiers in Microbiology 2016;7:1129.

Murakami AE, Oviedo-Rondón EO, Martins EN, Pereira MS, Scapinello C. Sodium and chloride requirements of growing broiler chickens (twentyone to forty-two days of age) fed corn-soybean diets. Poultry Science 2001;80:289-294

Olukosi OA, Cowieson AJ, Adeola O. Age-related influence of a cocktail of xylanase, amylase, and protease or phytase individually or in combination in broilers. Poultry Science 2007;86:77-86.

Onderci M, Sahin N, Sahin K, Cikim G, Aydín A, Ozercan I, et al. Efficacy of supplementation of $\alpha$-amylase-producing bacterial culture on the performance, nutrient use, and gut morphology of broiler chickens fed a corn-based diet. Poultry Science 2006;85:505-510. 
Oviedo-Rondón EO, Murakami AE, Furlan AC, Moreira I, Macari M. Sodium and chloride requirements of young broiler chickens fed corn-soybean diets (one to twenty-one days of age). Poultry Science 2001;80:592598.

Pieniazek J, Smith KA, Williams MP, Manangi MK, Vazquez-Anon M, Solbak $A$, et al. Evaluation of increasing levels of a microbial phytase in phosphorus deficient broiler diets via live broiler performance, tibia bone ash, apparent metabolizable energy, and amino acid digestibility. Poultry Science 2017;96:370-382.

Ravindran V, Cowieson AJ, Selle PH. Influence of dietary electrolyte balance and microbial phytase on growth performance, nutrient utilization, and excreta quality of broiler chickens. Poultry Science 2008;87:677-688.

Ravindran V, Morel PCH, Partridge GG, Hruby M, Sands JS. Influence of an Escherichia coli-derived phytase on nutrient utilization in broiler starter fed diets containing varying concentrations of phytic acid. Poultry Science 2006;85:82-89.

SAS Institute. SAS/STAT ${ }^{\circledR} 9.2$ User's guide. Cary; 2008.

Scholey DV, Morgan NK, Riemensperger A, Hardy H, Burton EJ. Effect of supplementation of phytase to diets low in inorganic phosphorus on growth performance and mineralization of broilers. Poultry Science 2018;97:2435-2440.

Selle PH, Ravindran V, Partridge GG. Beneficial effects of xylanase and/or phytase inclusions on ileal amino acid digestibility, energy utilisation, mineral retention and growth performance in wheat-based broiler diets. Animal Feed Science and Technology 2009;153:303-313.

Selle PH, Ravindran V. Microbial phytase in poultry nutrition. Animal Feed Science and Technology 2007;35:1-41.
Tripathi MK, Santra A, Chaturvedi OH, Karim SA. Effect of sodium bicarbonate supplementation on ruminal fluid $\mathrm{pH}$, feed intake, nutrient utilization and growth of lambs fed high concentrate diets. Animal Feed Science and Technology 2004;110:27-39.

Walk CL, Poernama F. Evaluation of phytase, xylanase, and protease in reduced nutrient diets fed to broilers. The Journal of Applied Poultry Research 2019;28:85-93.

Yaghobfar, A, Kalantar, M. Effect of non-starch polysaccharide (NSP) of wheat and barley supplemented with exogenous enzyme blend on growth performance, gut microbial, pancreatic enzyme activities, expression of glucose transporter (SGLT1) and mucin producer (MUC2) genes of broiler chickens. Brazilian Journal of Poultry Science, 2017; 19:629-638.

Yoruk MA, Gul M, Hayirli A, Lacin A. Laying performance and egg quality of hens supplemented with humate and sodium bicarbonate during the late laying period. Journal of Applied Animal Research 2004a;26:1721.

Yoruk, MA, Gul M, Hayirli A, Karaoglu M. Laying performance and egg quality of hens supplemented with sodium bicarbonate during the late laying period. International Journal of Poultry Science 2004b;3:272278 .

Yuan J, Wang X, Yin D, Wang M, Yin X, Lei Z, et al. Effect of different amylases on the utilization of cornstarch in broiler chickens. Poultry Science 2017;96:1139-1148.

Zakaria HA, Tabbaa MJ, Alshawabkeh KM, Altaif K. The effect of dietary sodium bicarbonate on performance and blood parameters of broiler chickens and local Balady breed inoculated with Salmonella gallinarum. Journal of Animal and Feed Sciences 2009;18:335-347. 